\title{
The overview of the technological approach to the colour revolution studies in the Russian political science
}

\section{A. Mamzelev ${ }^{1}$}

1P. G. Demidov Yaroslavl State University, 14 Sovetskaya str., Yaroslavl 150003, Russian Federation

DOI: $10.18255 / 2412-6519-2021-3-240-255$

Research Article Full text in Russian

The article represents a review of the technological approach to the phenomenon of colour revolutions that is prevalent in the modern Russian political science. The research identifies and critically examines key points of the technological approach: absence of valuable social reasons for colour revolutions, coup d'etat as combination of political technologies, manipulative nature of non-violent protest, inspiration of revolutionary process by concealed actors, anti-Russia orientation of colour revolutions. In the author's opinion, the technological approach can be useful for studies of political technologies applied by participants of the revolutionary confrontation. At the same time, a number of statements made by representatives of the technological approach, such as possibility of colour revolutions without social factors or anti-Russia vector of colour revolutions, don't seem wellgrounded. Election to the key political posts that determines further state development is a sufficient factor of colour revolutions, as it provokes politicization of the masses, competition of the regime and opposition, as well as wide media coverage of the political processes. The article also provides other approaches, such as common theory of revolution, theory of patronal presidentialism, studies of foreign influence. The author makes a conclusion of the necessity and efficiency of using analytical tools, proposed in various theories, both for educational and research purposes.

Keywords: colour revolutions; political technologies; socio-political crisis; theory of revolution; democratic transition; patronal presidentialism; revolutionary wave

INFORMATION ABOUT THE AUTHORS

\begin{tabular}{l|l} 
Mamzelev, Ilia A. & $\begin{array}{l}\text { E-mail: mamzel1207@mail.ru } \\
\text { Cand. Sc. (Politics), Associate Professor }\end{array}$
\end{tabular}

For citation: Mamzelev I. A. The overview of the technological approach to the colour revolution studies in the Russian political science // Social'nye i gumanitarnye znanija. 2021. Vol. 7, No 3. P. 240-255. (in Russ.) 


\title{
Обзор технологического подхода
}

\section{к изучению «цветных революций» в отечественной политической науке}

\author{
И. А. Мамзелев ${ }^{1}$
}

1Ярославский государственный университет им. П. Г. Демидова, ул. Советская, 14, Ярославль, 150003, Российская Федерация

DOI: $10.18255 / 2412-6519-2021-3-240-255$

удК 323

Научная статья

Полный текст на русском языке

В статье представлен обзор технологического подхода, получившего популярность в отечественной политологии, применительно к изучению феномена «цветных революций». Указываются и критически рассматриваются основные тезисы данного подхода: отсутствие значимых причин для «цветных революций», государственный переворот как комплекс политических технологий, ненасильственный протест как манипуляция, наличие скрытых инициаторов, антироссийская направленность. По мнению автора, технологический подход может быть полезен для изучения политических технологий, применяемых участниками революционного противостояния. При этом ряд утверждений представителей технологического подхода, таких как возможность проведения «цветных революций» в отсутствие социальных причин и антироссийский вектор «цветных революций», не представляется обоснованным. Достаточным основанием «цветных революций» являются выборы на ключевые политические должности, определяющие дальнейшее развитие страны, что обусловливает политизацию масс, конкуренцию режима и оппозиции, а также широкое освещение политических процессов в СМИ. В статье приводятся и другие подходы к изучению «цетных революций»: общая теория революции, теория демократического транзита, теория патрональных режимов, исследования внешнего влияния. Автор приходит к выводу о необходимости и продуктивности использования аналитических инструментов, предложенных в рамках различных теорий, как для образовательных, так и для исследовательских целей.

Ключевые слова: цветная революция; политическая технология; социально-политический кризис; теория революции; демократический транзит; патрональный президентский режим; революционная волна

\section{ИНФОРМАЦИЯ ОБ АВТОРАХ} Мамзелев, Илья Александрович
(автор для корреспонденции)
E-mail: mamzel1207@mail.ru

Кандидат политических наук, доцент кафедры социальнополитических теорий

Для цитирования: Мамзелев И. А. Обзор технологического подхода к изучению «цветных революций» в отечественной политической науке // Социальные и гуманитарные знания. 2021. Том 7, № 3. С. $240-255$.

(С) Мамзелев И. А., 2021

Статья открытого доступа под лицензией СС BY (https://creativecommons.org/licenses/by/4.0/) 
«Цветные революции» - нередкие составляющие политических процессов в разных странах с конца XX века. Их специфика как «революций с прилагательным» проявляется в том, что часто они имеют ненасильственный характер и происходят после выборов либо связаны с социально значимыми событиями, такими как приостановка подготовки соглашения об ассоциации с Евросоюзом, приведшая к Евромайдану на Украине в конце 2013 - начале 2014 гг.

Необходимо отдавать отчет в том, что понятие «цветные революции» носит прежде всего публицистический характер и появилось, скорее всего, благодаря журналистам, стремящимся привлечь внимание публики броским заголовком. Не существует единого и общепризнанного реестра «цветных революций», не имеется консенсуса в отношении того, какое явление обозначается данным понятием. Чаще всего к «цветным революциям» относят события в Сербии в 2000 г., Грузии в 2003 г., на Украине в 2004 и 2014 гг., в Киргизии в 2005 г., протесты в Белоруссии в 2006 и 2010 гг., «белоленточное движение» в России в 2011-2012 гг., а также «арабскую весну» в 2011 г. Очевидно, что недавние события в Армении 2018 г., Киргизии 2020 г. и продолжающееся движение в Белоруссии также можно отнести к данному ряду. Некоторые исследователи начинают историю «цветных революций» с событий на Филиппинах в 1986 г., когда ненасильственное протестное движение привело к отставке президента Фердинанда Маркоса, правившего страной с 1965 года [1, с. 147].

Революции, в том числе «цветные», как масштабные социальные процессы, затрагивающие общество и способные привести к радикальным политическим изменениям, отнюдь не всегда положительным, закономерно привлекают внимание как простых обывателей, так и специалистов. Социальные революции достаточно подробно изучены в политической науке. «Цветные революции» в связи с относительной новизной явления изучены чуть хуже, но к ним не утрачивается исследовательский интерес.

Целью данной статьи является рассмотрение и критика подхода, представленного не только в публицистике, но и в отечественной научной литературе по политологии. Считаем возможным определить данный подход как технологический, поскольку он интерпретирует «цветную революцию» как целенаправленно сконструированную и воспроизводимую в различных условиях технологию по захвату государственной власти. Для объективности обсуждения также кратко рассмотрим другие подходы, используемые при исследовании данного явления.

\section{Определения революции и «цветной революции»}

Определение революции, данное С. Хантингтоном, гласит, что это «быстрая, фундаментальная и насильственная смена доминирующих ценностей и мифов в обществе, в политических институтах, социальных структурах, лидерстве и политике государства» [2, с. 185]. Дж. Голдстоун предлагает другое определение: «революция - это насильственное свержение власти, осуществляемое посредством массовой мобилизации (военной, гражданской или той и другой вместе взятых) во имя социальной справедливости и создания новых политических институтов» [1, с. 15]. В обоих случаях отмечается насильственный характер революции. «Цветные революции», напротив, часто включают подчеркнуто ненасильственные движения.

Если говорить о «цветных революциях», то их определение должно подчеркнуть специфику данных социальных движений. Дж. Голдстоун говорит о «цветных революциях» как о «демократических», или «электоральных», массовых протестных движениях [Тамже. С. 147]. Один из первых исследователей «цветных революций» М. Макфол 
в своей публикации «Пути перехода от посткоммунизма» не употребляет данное понятие, предпочитая вместо него использовать сочетание «демократический прорыв» [3]. Отечественный специалист О. Г. Харитонова определяет «цветные революции» как постэлекторальные широкие движения оппозиции, направленные на восстановление провозглашенных режимом институциональных основ демократии, нарушенных в ходе выборов [2, с. 184].

Действительно, именно выборы на ключевые должности чаще всего представляют оптимальную институциональную конструкцию, способствующую возникновению «цветных революций»: она не только вовлекает основные политические силы с оформленными программами дальнейшего развития страны, но и мобилизует массы, а также создает лакуны в легитимности власть предержащих, когда политический статус избранных должностных лиц в основном зависит от поддержки избирателей и соблюдения процедур.

Напрашивается сходство «бархатных революций» в посткоммунистических странах в конце 1980-х - начале 1990-х годов и «цветных революций». И те, и другие имели относительно мирный, бескровный характер, но если первые привели к установлению демократических режимов и проведению либеральных экономических реформ, то вторые осуществлялись в условиях разочарования в успешности перехода к демократии, реставрации авторитарных порядков и расцвета патримониализма.

\section{Научная разработанность темы}

Как уже было упомянуто, одним из первых обратился к изучению «цветных революций» М. Макфол. Он выделяет 7 факторов, способствующих появлению и успеху «демократических прорывов» [3]:

1) полуавторитарный политический режим;

2) непопулярный инкумбент;

3) объединенная и организованная оппозиция;

4) возможность оперативно выявить фальсификации результатов голосования;

5) наличие независимых СМИ для информирования граждан о фальсификациях; массы;

6) способность политической оппозиции мобилизовать на протест широкие

7) раскол среди силовой опоры режима.

Обзор зарубежных и отечественных подходов к изучению «цветных революций» был сделан Н. А. Цветковой [4]. Как указывает исследователь, если для зарубежных концепций характерны мотивы ненасильственного сопротивления и демократизации режима, то для отечественных - темы внешнего вмешательства и демонтажа государственной системы. Важным отличием взгляда отечественного исследователя на проблему от зарубежного является восприятие «цветных революций» как угрозы в той или иной степени, прежде всего для России.

«Цветные революции» с точки зрения теорий демократизации рассмотрены 0. Г. Харитоновой [2]. Как и Н. А. Цветкова, она выделяет:

- теорию демократического транзита, в рамках которой «цветные революции» выступают как метод перехода к демократическому режиму (Г. О’Доннелл, Ф. Шмиттер, С. Хантингтон и др.);

- теорию ненасильственных действий, рассматривающую «цветные революции» с точки зрения способов и средств ведения конфликта (Дж. Шарп, П. Аккерман, К. Шок и др.); 
- структурный подход, изучающий объективные условия и структурные факторы «цветных революций»;

- процедурный подход, для представителей которого «цветные революции» являются результатом взаимодействия ключевых акторов социального процесса (оба подхода представлены в работах В. Банс, Ш. Уолчик, Г. Хейла, Л. Уэя, А. Пшеворски и др.);

- исследование внешних факторов «цветных революций» (В.Банс, Ш.Уолчик, С. Левицки, Л. Уэй и др.).

Убедительную попытку объединения подходов к изучению революций, в том числе тех, что произошли на постсоветском пространстве в конце XX - начале XXI веков, предпринимает Н. С. Розов [5]. Он строит динамическую модель революций, рассматривая механизмы и закономерности их развития. Среди факторов революционных процессов в постсоветских странах, помимо неспособности режима сохранить контроль над ситуацией и предотвратить формирование широкой оппозиционной коалиции, отмечается кризис клиент-патронажной сети: ослабляется гегемония властного центра, усиливается раскол элитных групп в борьбе за ренту; размывается важнейшее для режима отношение между властью и аутсайдерами (массами), позволяющее власти сохранять за собой ресурсы и статусы и не допускать к ним массы.

Таким образом, изучение «цветных революций» в современной политической науке характеризуется многообразием подходов. Вместе с тем с подачи консервативной публицистики в отечественную политологию и официальные нормативные документы попадает подход, который мы назовем технологическим.

\section{Технологический подход к изучению «цветных революций» в отечественной политологии}

Согласно данному подходу, «цветные революции» являются не «настоящими» революциями, а технологиями государственных переворотов, используемыми США для приведения к власти подконтрольных правителей, достижения глобального господства и, в конечном счете, смены власти в России. Несмотря на конспирологические нотки приведенных утверждений, технологический подход нашел свое отражение в Стратегии национальной безопасности Российской Федерации, утвержденной Указом Президента РФ от 31 декабря 2015 г. № 683: в данном документе инспирирование «цветных революций» рассматривается как одна из основных угроз государственной и общественной безопасности ${ }^{1}$. Кроме того, рассмотрение «цветных революций»как технологии по смене власти наблюдается в учебниках, таких как «Социальные технологии» под редакцией И. Б. Орловой [6] и «Политический менеджмент. Коммуникативные технологии» С. В. Чуева [7].

Рассмотрим более подробно основные тезисы технологического подхода.

Общим местом для многих публикаций отечественных авторов является рассмотрение «цветных революций» как технологического проекта по захвату власти.

По мнению профессора МГУ им. М. В. Ломоносова А. В. Манойло, «цветная революция» - это технология организации государственного переворота в условиях искусственно созданной политической нестабильности, в которой давление на власть осуществляется в форме политического шантажа, а основной движущей силой таранного удара по власти выступает специально организованное молодежное движение. [8, с. 25].

\footnotetext{
${ }^{1}$ О Стратегии национальной безопасности Российской Федерации: Указ Президента РФ от 31 декабря 2015 г. № 683 // ГАРАНТ.PУ. URL: https://base.garant.ru/71296054/ (дата обращения: 17.01.2021).
} 
Профессор МГИМО Е. Г. Пономарева предлагает следующее определение «цветных революций»: это государственный переворот, осуществленный с преимущественным использованием методов ненасильственной политической борьбы, силами «цветного» движения, как правило, в интересах и при непосредственном доминирующем участии в планировании, организации и финансировании со стороны иностранного государства, группы иностранных государств, общественных и коммерческих организаций [9].

Профессор Уральского федерального университета А. А. Керимов, рассматривая основные концепции «цветных революций» в отечественной политологии, заключает, что «цветные революции» «представляют собой целый спектр управляемых политических процессов и технологий, которые инициируются и внедряются извне иностранными или транснациональными заказчиками» [10, с. 7].

Далее рассмотрим основные содержательные черты технологического подхода к изучению «цветных революций» в российской политологии.

1. Отказ признать наличие действительно значимых причин для массовых протестов, являющихся движущей силой «цветных революций». Наличие таких причин отрицается, либо их значение преуменьшается. На примере украинских событий конца 2013 - начала 2014 гг. А. В. Манойло говорит об «искусственно созданной политической нестабильности» [8, с. 25]. Е. Г. Пономарева обращает внимание на то, что в случае с «цветными революциями» революционная ситуация, характерная для «классических» революций, отсутствует; правда, далее специалист признает, что «для успеха «цветных революций» необходим все-таки момент наибольших трудностей» [9].

Вместе с тем в каждом случае «цветной революции» в качестве триггера мы видим событие, которое привлекает внимание значительной части граждан и порождает повышенные ожидания; от результата данного события во многом зависит дальнейшее формирование политического курса. Это выборы президента страны («бульдозерная революция» в Сербии в 2000 г., «оранжевая революция» на Украине в 2004 г., события в Белоруссии в 2006, 2010 и 2020 гг.), выборы депутатов национального законодательного собрания («революция роз» в Грузии в 2003 г., протесты в Киргизии в 2005 и 2020 гг., белоленточное движение в России с конца 2011 года в знак протеста против нарушений на выборах депутатов Государственной Думы ФС РФ), определение внешнеполитической ориентации страны (киевский Евромайдан в 2013-2014 гг.), нарушение президентом страны ранее данного им обещания не баллотироваться на ключевой политический пост («бархатная революция» в Армении в 2018 г.). В большинстве этих случаев события были подкреплены длительным недовольством государственной политикой как со стороны рядовых граждан, так и со стороны части политических элит и неверием в нормальную работу политических институтов, призванных обеспечивать беспристрастность и объективность процессов передачи власти и ограничивать злоупотребления.

С учетом вышесказанного следует согласиться с Н. С. Розовым, который считает революцию возможным, но не обязательным следствием социально-политического кризиса, складывающегося из совокупности структурных факторов, неудачных ответов политической системы на поставленные вызовы и событий-триггеров, активизирующих развитие революционных процессов [5, с. 102]. Несмотря на все различия в трактовке социально-политического кризиса, он невозможен без утраты режимом легитимности в глазах широких слоев населения и части элит. Социально-политический кризис может не перерастать в массовые протесты, и это возможно как путем «закручивания гаек» (нарастания авторитарных тенденций, препятствования оппозиционной деятельности, сворачивания гражданских свобод), так и путем гибкого политического курса. 
Превращение кризиса в революцию - процесс, зависящий от ряда факторов. Представитель исторической макросоциологии Дж. Голдстоун выделяет пять структурных и процедурных условий возникновения революций:

1) проблемы в экономической и фискальной сферах, приводящие к непопулярным решениям власти, а также снижающие доходы широких слоев;

2) растущее отчуждение и оппозиционные настроения в среде элит, в результате чего часть элит может воспользоваться массовым недовольством, чтобы оказать давление на режим;

3) революционная мобилизация вследствие невозможности сохранять прежний образ жизни по не зависящим от людей обстоятельствам;

4) идеология, которая обосновывает требования справедливости со стороны элит и масс и обосновывает сопротивление режиму;

5) благоприятная международная обстановка, которая выражается в поддержке оппозиции [1, с. 30-35].

Наличие и действие факторов, обусловливающих возникновение революционных процессов, не всегда очевидно, что приводит к феномену «парадокса революций», когда начало и развитие волнений оказывается неожиданным для всех [Там же. С. 36-37].

Н. С. Розов, опираясь на модель функциональной причинности по А. Стинчкомбу, подробно исследует динамику революционных процессов. Согласно построениям Н. С. Розова, активность обеспечивающей структуры (в рассматриваемом случае - политического режима) по поддержанию некой целевой переменной (стабильности системы, политической легитимности, общественного согласия, массовой уверенности в компетентности режима) сопровождается определенными издержками (расходованием ресурсов). С ростом активности обеспечивающей структуры, появлением дополнительных действующих факторов растет напряжение. До определенных пределов рост напряжения не заметен и не отражается на целевой переменной. Однако с превышением пределов (резерва стабильности) напряжение прорывается, происходит обрушение стабильности системы [5, с. 107-110]. По мнению Н. С. Розова, момент «переключения» можно фиксировать по изменению общественной реакции на усилия режима, что подтверждает нашу мысль о кризисе легитимности действующей власти как ключевом элементе социально-политического кризиса.

Таким образом, внезапность революций в целом и «цветных революций» в частности не обязательно свидетельствует об искусственном характере данных социальных процессов. «Цветные революции» имеют те же основания, что и революции в целом: некомпетентность и недостаточная легитимность режима, раскол элит, политизация масс. Особенности «цветных революций» объясняются, прежде всего, конфигурацией политических институтов, социальных норм и сложившихся обстоятельств, а не хитроумной комбинацией.

2. «Цветные революции» - это комплекс политических технологий. Согласно рассматриваемому подходу, применение современных сетевых технологий и информационных манипулятивных технологий позволяет в короткие сроки, с минимальными затратами и без существенных на то предпосылок мобилизовать активные общественные силы на государственный переворот. В учебнике И. Б. Орловой отдельная глава посвящена анализу «цветной революции» как социальной технологии, «включающей разработку и последовательную реализацию научно обоснованных и скоординированных между собой этапов и соответствующих им операций и процедур для осуществления государственного переворота с целью достижения политической переориентации страны» 
[6, с. 128-147]. В пособии С. В. Чуева «Политический менеджмент. Коммуникативные технологии» перечисляется перечень технологий идеологической обработки населения и организации уличных мероприятий [7, с. 322-328].

Внимание к информационным и организационным технологиям, применяемым инициаторами протеста для влияния на общественное мнение, а также к методам организации массовых протестных акций, с нашей точки зрения, следует считать сильной стороной технологического подхода. Действительно, политические деятели всего мира используют различные средства убеждения, агитации, манипуляции для привлечения и мобилизации сторонников. Анализ политических технологий, применяемых сторонами, полезен для понимания и критической оценки происходящего, а также создания приемов противодействия.

При этом надо отдавать себе отчет в том, что к политическим технологиям прибегают все участники социальных процессов - как протестующие, так и режим. Было бы более справедливо рассматривать политические технологии информирования и агитации не как технологии захвата власти, а как технологии привлечения сторонников. Отдельного упоминания заслуживают технологии уличного противостояния, не сводимые к привычному электоральному процессу, - организации протестных акций, штурма и захвата ключевых точек и административных учреждений. Вместе с тем данные методы борьбы редко являются единственными, на которые опирается протест; обычно стороны выбирают из более широкого арсенала средств в различных сферах политической борьбы, перечисленных Н. С. Розовым: институциональная сфера, сфера мирной конкуренции вне формальных институтов и сфера политической борьбы без правил [11, с. 97-98].

Выбор акцента на том или ином поле определяется, исходя из оценки ситуации и динамики противостояния. Вместе с тем обычно стороны стремятся действовать в легальном пространстве, задействуя средства институциональной среды и мирной конкуренции и прибегая к крайним мерам, только когда иные средства исчерпаны. Традиционно «цветные революции» изображаются как массы разгневанных граждан на улицах, однако уличную борьбу чаще всего сопровождают переговоры политиков, парламентские дебаты и судебные иски.

3. Интерпретация ненасильственного протеста в ходе «цветных революций» как манипулятивной технологии. Как указывается в учебнике «Социальные технологии», «значительной слабостью многих демократических государств является то, что сотрудникам государственных структур и правоохранительных органов внушается мысль о недопустимости применения силы по отношению к тем, кто не совершает насильственные действия» [6, с. 132].

Приверженцы технологического подхода связывают ненасильственный протест с популярностью творчества Джина Шарпа (см., например, его работу «От диктатуры к демократии» [12]) и объясняют сходство революционных событий в разных странах тем, что революционеры пользуются одними и теми же «методичками». На наш взгляд, влияние трудов Шарпа преувеличено: в них нет каких-либо откровений, а лишь перечислены методы мирного гражданского сопротивления («политического неповиновения»), эффективность которых зависит от многих факторов и обстоятельств и потому на практике труднодостижима. Привлекательность и эффективность ненасильственного протеста объясняется просто: это приемлемый с точки зрения законодательства и социальных норм способ давления граждан и политических организаций на действующую власть. Благодаря осознанию значимости гражданских прав для политической стабильности, гражданского мира и экономического процветания с момента завершения Второй миро- 
вой войны международным сообществом была проделана большая работа по имплементации основных прав и свобод человека, включая возможность мирных собраний, в ключевые международные нормативные документы и конституции большинства стран (см., например, ст. 19 и 20 Всеобщей декларации прав человека). Чем выше в обществе доверие к политическим институтам и значимость демократических ценностей, тем с большей вероятностью протест будет мирным. Ненасильственный протест - это технология не смены власти, а политического давления на власть, предполагающая учет выраженного мнения при формулировании дальнейшего политического курса. Закрепление в законодательстве права на мирные акции протеста способствует тому, что они являются обычной практикой политического поведения во многих странах, не угрожают политической стабильности, а, напротив, способствуют снятию политического напряжения и обеспечивают функционирование всей политической системы. Препятствование данной практике путем введения избыточных норм, бюрократизации процесса организации акций, уголовного и политического преследования активистов - всё это в современных условиях само по себе является угрозой политической стабильности.

Следует также обратить внимание на монографию С. Пинкера, согласно которой снижение уровня насилия является долговременной глобальной тенденцией [13]. Данная тенденция не проявляется автоматически, но можно утверждать, что с повышением грамотности и развитием уровня образования, совершенствованием эффективности правоохранительной и правоприменительной системы, технологическим прогрессом, ростом уважения к ценностям и интересам женщин, применением научных подходов к решению социальных проблем в каждом конкретном обществе шансы на то, что мы увидим повторение кровавых событий революций 1789 или 1917 годов, существенно снижаются.

Почему во многих случаях «цветных революций» ненасильственный протест сопряжен с государственным переворотом? Следует отметить, что большинство рассматриваемых случаев, за исключением Евромайдана на Украине в 2013-2014 гг. и «бархатной революции» в Армении 2018 г., - это постэлекторальные революции, которые вызваны прошедшими избирательными кампаниями. Легитимность избранной в ходе выборов власти является, во-первых, процедурной, а во-вторых, опирается на концепцию народного суверенитета: власть достается тем, кто был поддержан большинством голосов. Именно процедурная легитимность оказывается под ударом, когда действующая власть обвиняется в фальсификации голосования, т. е. искажении волеизъявления народа. Эффект такого обвинения зависит от степени доверия к политическим силам, СМИ, общественным и политическим деятелям, иностранным государствам и международным организациям, которые заявили или поддержали данное обвинение, а также от имеющегося восприятия действующей власти: если она воспринимается как несправедливая, коррумпированная и неэффективная, то шансов на деятельную поддержку у нее будет немного.

Нетрудно заметить, что предпочтение ненасильственных методов с точки зрения их эффективности может противоречить целям захвата власти. Если абстрагироваться от соображений нравственности, подчас гораздо проще физически устранить сторонников режима, чтобы реализовать задуманное. Вместе с тем с точки зрения динамики политических процессов большое значение имеет легитимность их участников: в современном мире тот, кто первый прибег к насилию, может оказаться проигравшей стороной. Можно утверждать, что нахождение оптимального размещения на шкале

\footnotetext{
${ }^{1}$ Всеобщая декларация прав человека // Организация Объединенных Наций: сайт. URL: https://www.un.org/ru/documents/decl_conv/declarations/declhr.shtml (дата обращения: 17.01.2021).
} 
между ненасилием и инструментальной эффективностью является тактическим выбором участников революционного конфликта.

4. Наличие скрытых инициаторов «цветных революций». Гражданскому обществу в технологическом подходе отводится роль манипулируемого «пушечного мяса» рычага, с помощью которого происходит смена власти. Агентами манипуляций выступают политические партии, некоммерческие организации и СМИ. Конечными же бенефициарами и авторами «цветных революций» называются прежде всего США, которые используют их для достижения цели глобального господства. Как указывает Е. Г. Пономарева, «огромную роль <...> играет финансовая и организационно-информационная поддержка антисистемным силам из-за рубежа. При этом давлению подвергаются режимы лишь тех стран, в ресурсах, стратегическом или геополитическом положении которых заинтересован Запад» [9]. «Мягкая сила», концепция которой была предложена американским политологом Дж. Наем, рассматривается отечественными исследователями как механизм закрепления и расширения гегемонии Запада. С ракурса данной позиции социальные сети называются Е. Г. Пономаревой инструментом «цветных революций» [Там же]. В учебнике И. Б. Орловой «Социальные технологии» упоминается ряд американских организаций, которые содействуют распространению демократии в мире или которым «приписывают участие в разработке стратегии цветной революции и координации всех действий» [6, с. 133].

Истоки данного мнения следует искать в советско-американском противостоянии прошлого и высказанных Збигневом Бжезинским в 90-е гг. XX в. идеях о контроле над Евразией как основе глобального американского господства [14]. В период холодной войны США считали возможным военное вторжение в другую страну для установления дружественного режима: например, в 1983 г. произошла интервенция в Гренаду, в 1989 г. - в Панаму [15, с. 35]. Кроме того, известно, что уже в 2005 году президент США Дж. Бушмладший охарактеризовал меры по вестернизации захваченного войсками НАТО Ирака как «пурпурную революцию» [16].

Вместе с тем данная позиция имеет несколько слабых мест. Во-первых, деятельность по продвижению демократии не обязательно предполагает организацию государственного переворота. В первую очередь это поддержка некоммерческих организаций и гражданское просвещение. Во-вторых, финансовая поддержка не обязательно делает некоммерческие организации иностранными агентами, так как они могут использовать финансирование для достижения своих собственных целей. Исследовательница «цветных революций» В.Банс скептически рассматривает данный тезис: «Соединенные Штаты, конечно же, помогают организоваться этой оппозиции. Но теперь я вам открою самый страшный секрет, который я установила во время своих поездок в эти страны. Я никогда не видела, при всем бюрократическом головотяпстве американкой федеральной администрации, я никогда не видела настолько дурацки организованной программы, как программа распространения демократии по всему миру» [17].

Поиски американского вмешательства в честные демократические выборы в странах постсоветского пространства, как нам кажется, отвлекают от исследования внутренних причин происходящих в них процессов. На наш взгляд, «цветные революции» вызваны не столько стремлением США к мировому господству, сколько действием внутренних факторов: ухудшение положения широких масс населения, недовольство коррупцией в органах власти, националистические настроения и т. д. Здесь еще раз надо повторить основную мысль: внутренние процессы в обществе гораздо важнее внешних, хотя и испытывают их влияние. Обычно движущей силой «цветной революции» становились легальные участники избирательных кампаний, которые выражали требования различных слоев населения и были связаны с теми или иными политическими элитами 
и контрэлитами. Наличие таких сил обеспечивало институционализацию протеста, трансляцию требований в конвенциональное политическое пространство. Напротив, отсутствие представителей интересов протестующих в Белоруссии в августе 2020 года стало одним из факторов, препятствовавших успеху протестного движения.

Что касается рассмотрения «мягкой силы» как информационного инструмента доминирования Запада, то подобные интерпретации были подвергнуты критике профессором МГИМО М. М. Лебедевой. Она вслед за автором концепции Дж. Наем различает собственно «мягкую силу», предполагающую привлекательность той или иной страны, и пропаганду, о которой обычно говорят исследователи реалистского толка [18]. По мнению М. М. Лебедевой, в отличие от пропаганды, «мягкая сила» не предполагает навязывания и манипулирования, а потому не может сама по себе рассматриваться как инструмент информационной политики. Это скорее конкурентное преимущество, обусловленное технологическим развитием или институциональными особенностями.

5. Антироссийская направленность «цветных революций». «Цветные революции» подрывают власть России на территории ее исконных интересов и, в конечном счете, преследуют цель дестабилизации политической ситуации и смены власти в нашей стране. По мнению заместителя директора Института стратегических исследований и прогнозов РУДН Н. С. Данюка, «цветные революции» используются США для оказания давления на Россию, которая является сдерживающим фактором, не позволяющим США добиться глобального доминирования [19]. Как утверждает А. В. Манойло, «волна «цветных революций» не стала форматировать мусульманский Восток, а неожиданно проявилась на Украине - непосредственно у границ России. <...> Цель новой волны «цветных революций» не Украина и не режим Януковича, а Россия, ее суверенитет, территориальная целостность» [8, с. 26].

Данная позиция отнюдь не бесспорна. Более обоснованным представляется подход, согласно которому «цветные революции» вызваны внутренними структурными и процедурными факторами и направлены на решение вопросов, стоящих перед обществом соответствующих стран. Отношение к России, скорее всего, присутствует в повестке дня, однако в большинстве случаев не является ключевым вопросом. Как для широких слоев населения, так и для политических игроков первоочередным пунктом повестки в случае с «цветными революциями» является требование компетентного, справедливого, эффективного государственного управления. Вопросы отношения к России были в центре внимания, пожалуй, только событий на Украине в 2004 г., когда Россия поддерживала инкумбента и одного из участников президентских выборов, и 2013-2014 гг., когда поводом к событиям Евромайдана стало давление на президента Украины В. Януковича с целью достижения отказа от договоренностей об ассоциации с Евросоюзом.

При этом в формировании текущей практики отношений стран Центральной и Восточной Европы с Россией учитывается как опыт взаимодействия в рамках Организации Варшавского договора и СССР, а он скорее негативный, так и неоднозначный опыт событий последних лет. Отношение к данным странам как к территории исключительных российских интересов само по себе ущемляет их политическую субъектность и вредит задачам построения конструктивного и долгосрочного сотрудничества.

Таким образом, технологический подход, как нам представляется, существенно ограничивает возможности адекватного анализа событий цветных революций. Суммируя, можно назвать следующие наиболее очевидные его слабости:

1. Недооценка значения анализа политической ситуации, складывающейся в стране под воздействием структурных факторов и избираемых политическими субъек- 
тами стратегий и тактик поведения. Сложно предположить, что в благополучном обществе возможны такие масштабные потрясения, как революции и массовые протесты. В то же время, как мы знаем из достаточно недавнего опыта, даже при таких неблагоприятных факторах, как долговременное снижение доходов граждан, проблемы с легитимностью власти и враждебное внешнее окружение, революции не происходят или заканчиваются поражением. Поэтому полноценный структурный и ситуационный анализ необходим для корректного понимания обстоятельств, причин, механизмов и последствий революций.

2. Внимание к агентам, а не к факторам. Представители технологического подхода видят угрозу в политических субъектах. Для того чтобы устранить угрозу политической дестабилизации, достаточно разобраться с деструктивными силами. Представляется, что такая позиция может привести к «охоте на ведьм» и нарушению гражданских прав. Перезапуск каналов обратной связи с гражданским обществом, формирование устойчиво работающих политических институтов, допуск к благам, ресурсам и статусам широких общественных слоев, внедрение принципов достойного правления - вот какие шаги способны предотвратить социально-политический кризис.

3. Не всегда оправданное стремление искать «длинную руку» Запада. Роль внешних факторов в «цветных революциях» достаточно велика. Однако эти факторы не сводятся к финансированию государственных переворотов или военному вторжению. Это может быть дипломатическая поддержка, это могут быть акции солидарности, публикации в СМИ или общая привлекательность культуры и образа жизни другого государства. Внешнее влияние может даже тормозить революционные процессы, как это происходит в случае с современными протестами в Белоруссии. Кроме того, действенность того или иного воздействия требует объективной оценки. Обвинение внешних врагов в инспирировании «цветных революций» хорошо работает как риторический прием, но не годится в качестве аналитического инструмента.

\section{Обзор других подходов к изучению «цветных революций»}

Кратко рассмотрим другие подходы к исследованию «цветных революций», представленные в политической науке.

1. Общая теория революции. Исследователи указывают на несколько этапов развития общей теории революции, спровоцированных политическими событиями в мировой истории. Обзор развития концепций представлен в статьях Дж. Голдстоуна и Э. Э. Шульца [20; 21].Дж. Голдстоун рассматривает «цветные революции» в общем ряду революций, объясняя их специфику действием таких факторов, как изменение глобальных стандартов легитимности, требующих проведения выборов; технологический прогресс, расширивший возможности оппозиции по распространению своих взглядов; формирование международной сети активистов, обучающих методам ненасильственного сопротивления; ослабление мотивации держав к военному вмешательству во внутреннюю политику других государств с завершением «холодной войны» [1, с. 146-147].

Э. Э. Шульц скептически относится к предложенной Дж. Голдстоуном классификации историографии революций, справедливо указывая на искусственный характер ее критериев. Вместе с тем исследования «цветных революций» он считает возможным отнести к 5-му поколению работ, появление которого было вызвано необходимостью «переварить» фактологический материал событий начала XXI в. [21, с. 172].

Изучение общей теории революции позволяет оценить различные концептуальные построения исследователей и проследить развитие научной мысли. Важным пред- 
ставляется то, что обращение к общей теории революции позволяет рассмотреть «цветные революции» как отдельную группу общего рода явлений, чья специфика обусловлена изменением международного контекста, распространением информационно-коммуникационных технологий и усилением взаимодействия неправительственных организаций.

2. Теория демократического транзита. Данная теория трактует «цветные революции» в духе глобальной тенденции демократизации. Здесь надо отметить, что еще С. Хантингтон рассматривал «замену» (приход к власти бывших оппозиционных групп) как один из форматов третьей волны демократизации [15, с. 156].

В своей статье «Пути перехода от посткоммунизма» М. Макфол отмечал значимые отличия «цветных революций» в Сербии, Грузии и на Украине от более ранних демократических переходов: фальсификации на национальных выборах как повод для смены режима; использование оппозицией внеконституционных средств для защиты конституции; конкуренция оппозиции с инкумбентом за суверенную власть; неприменение массового насилия [1, с. 6].

С конца 1990-х годов оптимизм по поводу всеобщего неизбежного перехода к демократии угас. Это отразилось и на применении теории демократического транзита к изучению «цветных революций». Б. В. Грызлов закономерно указывал на сомнительность демократического характера постреволюционной ситуации в странах, в которых произошли цветные революции [22].

Действительно, «цветные революции» не всегда приводят к демократии, и в фокус дальнейших научных изысканий приверженцев данного направления входит изучение факторов, влияющих на результаты транзитов. А. Ю. Мельвиль указывает на наличие двух альтернативных объяснительных моделей перехода к демократии. Первая, «структурная» модель предполагает для успешного демократического перехода наличие «объективных» процессов и предпосылок, таких как относительно высокий уровень экономического развития, политическая культура «гражданского» типа, отсутствие в обществе непримиримых или острых расколов, религиозные традиции протестантизма и католицизма, качество институтов и т. д. [23, с. 165-167]. Вторая модель («процедурная») акцентирует внимание на таких субъективных факторах, как расклад политических сил, решения и действия политических субъектов: характер и особенности «выхода» из авторитаризма, роль и влияние институционального дизайна, взаимодействие между ключевыми политическими игроками, сохранение старых элит, отношение власти к политическому плюрализму, качество проводимых выборов, использование властью или оппозицией насилия и т. д. [23, с. 168].

Таким образом, теория демократического транзита может быть полезна для исследователей «цветных революций», так как она обращает внимание на структурные и процедурные факторы, влияющие на специфику как хода, так и результата «цветных революций».

3. Теория патрональных режимов. Данная теория представляет собой развитие режимного подхода с учетом критики утверждений о демократизации режимов в результате цветных революций. В частности, Г. Хейл указывает на формирование в большинстве бывших советских республик системы патронального президентского правления, которая характеризуется как значительными формальными полномочиями у президента по сравнению с другими ветвями власти, так и широким набором неформальных полномочий, основанных на патрон-клиентских отношениях между президентом и элитами [24].

Патрон-клиентские отношения в условиях широких полномочий президента обеспечивают лояльность элит действующей власти - до того момента, пока не появляется 
вероятность ухода президента-патрона с должности, в результате чего у элит появляется возможность связать свое будущее с возможными преемниками или конкурентами. Это может привести к нарастанию внутриэлитного соперничества, в ходе которого стороны могут воспользоваться и таким инструментом, как массовая мобилизация и организация протестных митингов, и появлению революционной ситуации. Г. Хейл обращает внимание на то, что «цветные революции» 2003-2005 гг. развивались вскоре после того, как инкумбент давал понять об отсутствии планов на переизбрание, после чего запускался механизм поиска элитами нового потенциального «патрона».

А. А. Фисун продолжил применение теории патрональных режимов к исследованию цветных революций [25]. По его мнению, ключевой предпосылкой «цветных революций» следует считать неспособность интегрировать в клиент-патронажную сеть значительные сегменты элит, что приводит к постепенной утрате режимом поддержки большинства. Главным результатом цветных революций является изменение политики распределения ресурсов в пользу победителей.

Н.С. Розов считает неопатримониальные (патрональные) режимы довольно устойчивыми, а возможности их демократизации незначительными и требующими наличия внушительного перечня условий:

1) делегитимация представителей режима и принципов его функционирования;

2) неприменение в ходе политической борьбы крайних и затяжных форм насилия;

3) выход победившей коалиции за рамки клиент-патронажной сети;

4) формирование «пакта элит» в условиях отсутствия доминирующего лидера, способного подавить остальных;

5) успешное проведение не менее 2 избирательных циклов со сменой власти по результатам выборов и т. д. [5, с. 74-75].

Таким образом, теория патрональных режимов углубляет исследование институциональных предпосылок «цветных революций» концепцией клиент-патронажных сетей, вовлекающих сильного президента и элитные группы в неформальные отношения: протяженность сетей и регулярность предоставления благ со стороны власти обеспечивают лояльность вовлеченных элит, а сужение сетей и возникновение сомнения в дееспособности инкумбента заставляют элиты конкурировать между собой и искать новых потенциальных «патронов».

4. Исследования внешнего влияния. Процессы глобализации, происходящие в современном мире, не позволяют преуменьшать влияние внешних факторов на внутреннюю ситуацию в стране, в том числе на «цветные революции». Международное сообщество направляет наблюдателей для контроля над ходом голосования, освещает информацию в СМИ, оказывает политическое давление на стороны конфликта (в большинстве рассмотренных случаев - на представителей действующей власти), часто поддерживает оппозицию. Всё это является значимыми факторами, влияющими на поведение режима и протестующих. Вместе с тем, на наш взгляд, следует дифференцировать влияние в зависимости от формы поддержки или противодействия. Кроме того, согласно исследованию С. Левицки и Л. Вэя, значение имеет плотность связей гибридного режима с Западом: тесная интеграция обеспечивает постепенную демократизацию, в то время как слабость связей с Западом наряду с высокой внутренней организацией способствует дрейфу в сторону стабильных автократий, а слабость внутренней организации приводит к зависимости от более сильного соседа [26, с. 26].

Альтернативным подходом можно считать теорию революционных волн. Безусловно, государства не существуют в полном вакууме, а внутренние политические процессы никогда не были абсолютно внутренними и всегда испытывали влияние извне. 
Особенно это справедливо для современности. С конца XX в., в том числе благодаря цветным революциям, в центре внимания исследований оказываются революционные волны - серии близких во времени революционных событий, которые происходят в различных (нередко соседних) обществах, служат причинами друг друга или имеют общие причины. Так, коллектив специалистов под руководством Н. С. Розова рассматривает такие виды революционных волн, как домино-волны (обусловлены сильным эмоциональным эффектом), индуцированные (обусловлены переносом технологий организации, литературы, революционеров), полемогенные (причиной которых становятся вооруженные конфликты), идейные (вызываются общностью лозунгов, идей, идеологий) и структурные волны (активируются общими базовыми причинами) [27].

\section{Выводы}

На наш взгляд, технологический подход к изучению «цветных революций» имеет право на существование, однако нуждается в расширении перечня объектов и глубины анализа, а также в исключении априорных суждений.

Целесообразно, помимо технологического, предлагать в учебных пособиях по политологии другие подходы к анализу рассматриваемой темы, чтобы студенты и заинтересованные лица могли сравнить ставящиеся различными подходами вопросы и получаемые ответы, критически подойти к их оценке и выбрать наиболее подходящую для себя позицию.

Что касается непосредственно анализа «цветных революций» и социально-политических кризисов, то для их корректного и беспристрастного изучения технологический подход следует применять совместно с методологическими инструментами, предлагаемыми различными теориями и подходами.

\section{Ссылки / References}

1. Голдстоун Д. Революции. Очень краткое введение. М.: Изд-во Института Гайдара, 2015. 192 с.

2. Харитонова О. Г. Цветные революции в контексте теорий демократизации // Политическая наука. 2014. № 3. С. 184-210.

3. McFaul M. Transitions from Postcommunism // Journal of Democracy. July 2005. Vol. 16. № 3. P. 5-19.

4. Цветкова Н. А. Дискурс «цветных революций» // Постсоветские исследования. 2019. Т. 2. № 2. С. $940--950$.

5. КРАСАНД, 2019. 336 с.

6. Социальные технологии: учебное пособие для бакалавриата и магистратуры / Под ред. И. Б. Орловой. М.: Юрайт, 2019. 174 с.

7. Чуев С.В. Политический менеджмент. Коммуникативные технологии. М.: Издательство Юрайт, 2017. 364 с.

8. Манойло А. В. Украинский кризис и «управляемый хаос»: след «цветных революций» арабской весны // Власть. 2014. № 4. С. 24-28.

9. Пономарева Е. Секреты «цветных революций» // LiveJournal: сайт. URL: https://imhotype.livejournal.com/150888.html (дата обращения: 27.12.2020). 
10. Керимов А. А., Вербицкая Т. В. Цветная революция как угроза политической системе государства: проблемы определения // Вопросы управления. 2019. № 2 (38). С. 6-15.

11. Розов Н. С. Кризис и революция: поля взаимодействия, стратегии акторов и траектории конфликтной динамики // Полис. Политические исследования. 2017. №6. С. 92-108.

12. Шарп Д. От диктатуры к демократии. Стратегия и тактика освобождения. М.: Новое издательство, 2005. 84 с.

13. Пинкер С. Лучшее в нас: Почему насилия в мире стало меньше. М.: Альпина нон-фикшн, 2021. 952 c.

14. Бжезинский 3. Великая шахматная доска. М.: Междунар. отношения, 1998. 254 с.

15. Хантингтон С. Третья волна. Демократизация в конце XX века. М.: Российская политическая энциклопедия, 2003. 368 с.

16. Пурпурная революция // Википедия: сайт.

https://ru.wikipedia.org/wiki/\%D0\%9F\%D1\%83\%D1\%80\%D0\%BF\%D1\%83\%D1\%80\%D0\%B D\%D0\%B0\%D1\%8F_\%D1\%80\%D0\%B5\%D0\%B2\%D0\%BE\%D0\%BB\%D1\%8E\%D1\%86\%D0\%B 8\%D1\%8F (дата обращения: 17.01.2021).

17. Банс В. Цветные «революции через выборы»: почему они произошли и кто следующий? // Институт общественного проектирования: сайт. URL: http://www.inop.ru/reading/Bunce/ (дата обращения: 09.11.2020).

18. Лебедева М. М. «Мягкая сила»: понятие и подходы // Вестник МГИМО-Университета. 2017. № 3 (54). C. 212-223.

19. Данюк Н. С. «Цветные революции» как внешнеполитический инструмент США для обеспечения глобального доминирования в контексте формирования нового миропорядка // Вестник КГУ. 2017. № 2. С. 46-51.

20. Голдстоун Д. К теории революции четвертого поколения // Логос. 2006. № 5 (56). С. 58-103.

21. Шульц Э. Э. Теория революции: к истории изучения, систематизации и современному состоянию // Научные ведомости. Серия «История. Политология. Экономика. Информатика». 2015. № 1 (198). Вып. 33. С. 167-172.

22. Грызлов Б. В. «Цветные революции»: имел ли место «демократический прорыв»? // Вестник Санкт-Петербургского университета. Сер. 6. 2006. Вып. 3. С. 64-69.

23. Мельвиль А. Ю., Стукал Д. К. Условия демократии и пределы демократизации. Факторы режимных изменений в посткоммунистических странах: опыт сравнительного и многомерного статистического анализа // Полис. Политические исследования. 2011. № 3. C. 164-183.

24. Хейл Г. Президентский режим, революция и демократия // Полит.ру: сайт. URL: https://polit.ru/article/2008/05/26/hale/ (дата обращения: 10.01.2021).

25. Фисун А. Политическая экономия «цветных» революций: неопатримониальная интерпретация // Прогнозис. Осень 2006. № 3 (7). С. 211-244.

26. Шульман Е. Практическая политология. Пособие по контакту с реальностью. М.: АСТ, 2018. 320 c.

27. Революционные волны в Европе и мире как следствия и факторы глобальной модернизации / Н. С. Розов, Ю. А. Пустовойт, С. И. Филиппов, В. В. Цыганков // Вестник РФФИ. Гуманитарные и общественные науки. 2019. № 3. С. 102-111. 